Article

\title{
Poor Dietary Quality Is Associated with Increased Inflammation in Swedish Patients with Rheumatoid Arthritis
}

\author{
Linnea Bärebring ${ }^{1}$, Anna Winkvist ${ }^{1}$, Inger Gjertsson ${ }^{2}$ and Helen M. Lindqvist ${ }^{1, *(1)}$ \\ 1 Department of Internal Medicine and Clinical Nutrition, Sahlgrenska Academy, University of Gothenburg, \\ Box 459, 40530 Gothenburg, Sweden; linnea.barebring@gu.se (L.B.); anna.winkvist@nutrition.gu.se (A.W.) \\ 2 Department of Rheumatology and Inflammation Research, Sahlgrenska Academy, University of \\ Gothenburg, Box 480, 40530 Gothenburg, Sweden; inger.gjertsson@rheuma.gu.se \\ * Correspondence: helen.lindqvist@gu.se; Tel.: +46-31-786-3723
}

Received: 10 September 2018; Accepted: 15 October 2018; Published: 18 October 2018

\begin{abstract}
The aim was to study whether dietary quality was associated with disease activity and inflammation among patients with rheumatoid arthritis (RA). This cross-sectional analysis included 66 Swedish participants, who each completed a food frequency questionnaire (FFQ) at screening. Food intake was scored by a dietary quality index created by the Swedish National Food Agency. Disease activity was measured as Disease Activity Score 28 (DAS28), based on erythrocyte sedimentation rate (ESR), a patient administered visual analogue scale of perceived global health and the number of tender and swollen joints out of 28 examined. Inflammation was measured as ESR and C-reactive protein (hs-CRP). Associations between dietary quality, disease activity and inflammation were evaluated using multivariable linear regression analysis. High dietary quality (high intake of fish, shellfish, whole grain, fruit and vegetables and low intake of sausages and sweets) was not related to DAS28 ( $\mathrm{B}=-0.02, p=0.787)$. However, dietary quality was significantly negatively associated with hs-CRP $(\mathrm{B}=-0.6, p=0.044)$ and ESR $(\mathrm{B}=-2.4, p=0.002)$ after adjusting for body mass index, age, education, smoking and gender. Both hs-CRP and ESR decreased with increasing dietary quality. In conclusion, among patients with RA, high dietary quality was associated with reduced inflammation but not with disease activity.
\end{abstract}

Keywords: diet; C-reactive protein; blood sedimentation; inflammation; rheumatoid arthritis

\section{Introduction}

Rheumatoid Arthritis (RA) is a chronic autoimmune disease that affects $0.5-1 \%$ of the Western population. In Sweden, the incidence of RA is about 41 per 100,000 [1]. The disease is characterized by painful joint inflammation, which causes irreversible joint destruction, disabilities and reduced quality of life. Pharmacological treatment of RA has become much more effective, but approximately only half of the patients with newly diagnosed RA in 2016 in Sweden reached remission, i.e., no active disease [2]. This indicates that other treatment modalities, alongside the pharmacological treatment, should be explored in order to decrease disease activity and inflammation in patients with RA.

A number of individual factors such as age, gender, body mass index (BMI), smoking and diet can influence and modify the inflammatory response [3]. Diet has the potential to decrease inflammation and disease activity in RA, through several pathways: e.g., dietary fatty acids influence the production of cytokines and eicosanoids, and a reduced intake of arachidonic acid and an increased intake of long chain omega three fatty acids, can ameliorate symptoms of RA [4]. Additionally, antioxidant intake might reduce the level of inflammation markers by reducing oxidative stress $[5,6]$. 
Further, gut microbiota might mediate inflammatory responses and may itself be improved by preand probiotics $[7,8]$ which indicates a role for dietary fiber.

Gender, higher BMI and age are associated with higher disease activity and inflammation in RA [9]. Higher BMI and smoking are also risk factors in developing RA [10,11]. Further, being overweight at diagnosis is associated with a decreased chance of adequate disease control [12]. In addition, research indicates that poor dietary quality may be an independent risk factor in developing RA. For example, intake of sugar sweetened soda [13] is associated with an increased risk while long chain n-3 fatty acids [14], vegetables and dairy [15], and the Mediterranean dietary pattern [16] are associated with decreased risk. However, associations between diet and the risk of developing RA have not been confirmed in all studies $[17,18]$.

In established RA, diet may be of importance for disease progression. Regrettably, patients with RA have unsatisfactory dietary quality, and poorer diet than healthy controls [19,20]. Poor dietary quality is associated with longer lasting morning stiffness [19] and more functional disabilities [20]. Other studies have shown that higher disease activity is associated with lower intake of fish oil, monounsaturated fatty acids [21] and n-3 polyunsaturated fatty acids [22]. Few intervention studies have investigated dietary treatment for decreasing disease activity and inflammation in RA, but some positive results have been noted for the Mediterranean diet [23,24], gluten free vegan diet [25] and fasting followed by vegan and vegetarian diet [26,27]. Overall, there are indications that dietary intake could modify disease activity and inflammation in RA. Possibly, a higher intake of dietary fiber (plant-based foods such as fruit and vegetables and whole grain) and a high-quality fat intake (lower intake of saturated fats and a higher intake of unsaturated and long-chain polyunsaturated fatty acids) could contribute to decreased inflammation and disease activity. However, despite indications from patients with RA that dietary intake impacts the disease [28], there is a great lack of research in this area.

The aim of this cross-sectional study was to determine whether dietary quality was associated with disease activity and inflammation among patients with RA in Sweden.

\section{Materials and Methods}

Participants were recruited to the randomized cross-over trial ADIRA (Anti-inflammatory Diet in Rheumatoid Arthritis) [29] during 2017 and the data presented here are based on the initial screening visit. The study was registered at Clinical Trials prior to recruitment (NCT02941055). Patients in the region of Västra Götaland, Sweden, were identified through the Swedish Rheumatology Quality Registry. In total, 1091 patients ( 244 men, 847 women) were considered eligible and 774 patients resided within reasonable distance from the Sahlgrenska University Hospital, Gothenburg, Sweden, and were therefore invited to participate. Inclusion criteria for the intervention study were age $>18$ years, disease duration $\geq 2$ years, stable pharmacological treatment during the last 3 months and a willingness to consume an omnivore diet. Exclusion criteria were other serious illness, longer travel time, planned surgery, pregnancy and a food allergy or avoidance of foods included in the intervention study. A total of 113 individuals showed interest in participating in the study. Those $(N=47)$ who did not fulfil the inclusion criteria after initial contact were excluded. A total of 66 patients were screened during a visit to the Sahlgrenska University Hospital and were included in the present cross-sectional analysis. This study was conducted according to the Declaration of Helsinki and all procedures were approved by the Regional Ethics Committee in Gothenburg (No. 976-16, of November 2016). Written and informed consent was provided by all participants.

Food intake at baseline was reported by a 53-item food frequency questionnaire (FFQ), reflecting dietary intake during the last 12 months. Overall diet quality was calculated by a dietary quality index created by the Swedish National Food Agency [30], based on the dietary recommendations in the Nordic Nutrition Recommendations [12]. Briefly, dietary quality is scored by consumption frequency of the following foods; fruit and vegetables, whole grain bread, fish and shellfish, fat spreads, cheese ( $24-40 \%$ fat), sausage and discretionary foods (sweets, cakes, soft drinks 
and fried potatoes). Frequent consumption of fruit, vegetables, whole grain bread and fish contribute positively to the index score, while intake of cheese, sausage and discretionary foods contribute negatively. Habitual use of low-fat spread $(\leq 40 \%)$ contributes positively while high fat spread $(\geq 60 \%)$ contributes negatively. The index is an indicator of dietary quality (intake of fat, sugar and fiber) and compliance with dietary recommendations (intake of fruit, vegetables, fish and whole grain bread). The total score ranges from 0 to 12 , and dietary quality considered low at $0-4$ points, fair at 5-8 points and high at $9-12$ points [30].

Disease activity was defined by Disease Activity Score 28 (DAS28), which is a composite score based on the examination of 28 joints in combination with the erythrocyte sedimentation rate (ESR) and the patients' perceived health on a visual analogue scale. ESR and high sensitivity C-reactive protein (hs-CRP) were measured at the routine laboratory for Clinical Chemistry at Sahlgrenska University Hospital. BMI was calculated using weight and height measured at the screening visit. Data on education and smoking were collected using patient administered questionnaires. Education level was classified into primary level, secondary level or university level. Smoking referred to current use and was coded as a binary variable (yes/no).

The ADIRA randomized cross over trial needed 38 participants to detect a significant difference of 0.6 units of DAS28 between the diet groups ( $80 \%$ power), and screened 66 individuals. Based on observational dietary data among individuals at cardiometabolic risk [31], a group size of 44 would yield sufficient statistical power to detect differences in hs-CRP ( $6 \mathrm{vs.} 3 \pm 5 \mathrm{mg} / \mathrm{L}$ ) between those with high and poor dietary quality (80\% power, alpha 0.05$)$.

Gender differences in dietary quality and categorical participant characteristics were studied using the Chi-square test. Gender differences in continuous participant characteristics were studied using the Mann Whitney-U test and Student's $t$-test. Dietary quality was studied in relation to DAS28, hs-CRP and ESR using multivariable linear regression analysis. Dietary quality was used both as a continuous variable (0-12) and classified into poor (0-4), fair (5-8) and high (9-12) quality. DAS28 was categorized as remission $(<2.6)$, low disease activity $(2.6-3.2)$ and moderate-high disease activity $(>3.2)$. Both crude and adjusted models are presented, and all multiple models are adjusted for age, BMI, education level, gender and smoking. Statistical analyses were performed using software SPSS Statistics 25.0 (IBM). Significance was accepted at $p<0.05$.

\section{Results}

The age ranged from 27-74 years and the study included subjects from normal weight to obesity. In total, $80 \%$ of the participants were female, $55 \%$ were educated at university level and $5 \%$ smoked (Table 1). A total of $26 \%$ of the participants were in remission (DAS28 <2.6), $21 \%$ had low disease activity (DAS28 2.6-3.2), 49\% had moderate disease activity (DAS28 3.2-5.1) and 5\% had high disease activity (DAS28 $>5.1)$.

The median (Q1-Q3) dietary index score was 6.5 (5.0-7.0) points, and ranged from 0 to 10 points. The median dietary index scores among women and men were 6.4 and 5.5 , respectively $(p=0.074)$. Most participants reported consuming fruit and vegetables 1-2 times/day and most reported consuming fish and shellfish 3-6 times/week (Table 2). Margarine ( $\geq 60 \%$ fat) or butter as spread was favored by $73 \%$ of the participants while $27 \%$ reported using low fat margarine ( $\leq 40 \%$ fat). Dietary quality was classified as fair for most participants (76\%), while $15 \%$ and $9 \%$ had a poor or high-quality diet, respectively. Women reported more frequent intake of fruit and vegetables than did men, but no other significant gender differences in reported dietary intake were noted (Table 2). There was a tendency towards younger age among participants with poor dietary quality (Table 1). 
Table 1. Characteristics of the 66 Swedish patients with rheumatoid arthritis.

\begin{tabular}{|c|c|c|c|c|c|c|c|c|c|}
\hline & \multicolumn{2}{|c|}{$\begin{array}{c}\text { All } \\
N=66\end{array}$} & \multicolumn{2}{|c|}{$\begin{array}{c}\text { Poor Dietary } \\
\text { Quality }(N=10)\end{array}$} & \multicolumn{2}{|c|}{$\begin{array}{c}\text { Fair Dietary } \\
\text { Quality }(N=50)\end{array}$} & \multicolumn{2}{|c|}{$\begin{array}{c}\text { High Dietary } \\
\text { Quality }(N=6)\end{array}$} & \multirow[b]{2}{*}{$p^{\mathrm{a}}$} \\
\hline & Mean & SD & Mean & SD & Mean & SD & Mean & SD & \\
\hline Dietary quality & 6.2 & 1.9 & 3.1 & 1.2 & 6.5 & 1.1 & 9.5 & 0.6 & $<0.001$ \\
\hline Age (years) & 59.9 & 12.2 & 52.8 & 13.0 & 60.6 & 12.1 & 65.9 & 8.1 & 0.096 \\
\hline BMI $\left(\mathrm{kg} / \mathrm{m}^{2}\right)$ & 27.6 & 5.1 & 26.1 & 5.1 & 28.0 & 5.0 & 26.2 & 5.7 & 0.412 \\
\hline Waist hip ratio & 0.86 & 0.08 & 0.90 & 0.10 & 0.86 & 0.08 & 0.83 & 0.05 & 0.325 \\
\hline DAS28 (ESR) & 3.4 & 1.1 & 3.3 & 0.9 & 3.5 & 1.1 & 2.9 & 1.3 & 0.528 \\
\hline hs-CRP & 3.9 & 5.0 & 6.4 & 6.2 & 3.7 & 4.9 & 1.8 & 1.7 & 0.066 \\
\hline ESR & 17.5 & 11.7 & 22.5 & 9.8 & 17.3 & 12.2 & 10.8 & 7.2 & 0.105 \\
\hline General Health VAS (mm) & 36.5 & 22.4 & 31.0 & 17.5 & 37.1 & 22.3 & 40.0 & 32.3 & 0.831 \\
\hline Tender joint count & 3.36 & 3.9 & 1.8 & 2.4 & 3.8 & 4.2 & 2.3 & 3.3 & 0.172 \\
\hline \multirow[t]{2}{*}{ Swollen joint count } & 1.7 & 1.7 & 1.2 & 1.2 & 1.8 & 1.8 & 1.3 & 2.0 & 0.499 \\
\hline & \multicolumn{2}{|c|}{$\begin{array}{c}\text { All } \\
N=66\end{array}$} & \multicolumn{2}{|c|}{$\begin{array}{c}\text { Poor Dietary } \\
\text { Quality }(N=10)\end{array}$} & \multicolumn{2}{|c|}{$\begin{array}{c}\text { Fair Dietary } \\
\text { Quality }(N=50)\end{array}$} & \multicolumn{2}{|c|}{$\begin{array}{c}\text { High Dietary } \\
\text { Quality }(N=6)\end{array}$} & $p^{\mathbf{b}}$ \\
\hline Education level & $\mathbf{N}$ & $\%$ & $\mathbf{N}$ & $\%$ & $\mathbf{N}$ & $\%$ & $\mathbf{N}$ & $\%$ & 0.589 \\
\hline Primary level & 10 & 15 & 1 & 10 & 9 & 90 & 0 & 0 & \\
\hline Secondary level & 20 & 30 & 4 & 20 & 13 & 65 & 3 & 15 & \\
\hline University level & 36 & 55 & 5 & 14 & 28 & 78 & 3 & 8 & \\
\hline Smoking & & & & & & & & & 0.605 \\
\hline No & 63 & 95 & 9 & 14 & 48 & 76 & 6 & 10 & \\
\hline Yes & 3 & 5 & 1 & 33 & 2 & 67 & 0 & 0 & \\
\hline Gender & & & & & & & & & 0.342 \\
\hline Female & 53 & 80 & 7 & 13 & 40 & 75 & 6 & 11 & \\
\hline Male & 13 & 20 & 3 & 23 & 10 & 77 & 0 & 0 & \\
\hline
\end{tabular}

${ }^{a}$ Derived from Kruskal Wallis test, ${ }^{\mathrm{b}}$ Derived from Chi square test; BMI, body mass index; DAS28, disease activity score 28-joints; ESR, Erythrocyte sedimentation rate; VAS, visual analogue scale.

Table 2. Dietary intake of the 66 Swedish patients with rheumatoid arthritis.

\begin{tabular}{|c|c|c|c|c|}
\hline & $\begin{array}{l}\text { Percent, All } \\
\quad(N=66)\end{array}$ & $\begin{array}{l}\text { Percent, Women } \\
\quad(N=53)\end{array}$ & $\begin{array}{l}\text { Percent, Men } \\
\quad(N=13)\end{array}$ & $p$ \\
\hline Dietary quality & & & & 0.342 \\
\hline Poor (0-4 points) & 15 & 13 & 23 & \\
\hline Fair (5-8 points) & 76 & 76 & 77 & \\
\hline High (9-12 points) & 9 & 11 & 0 & \\
\hline Fruit and vegetables ${ }^{a}$ & & & & $<0.001$ \\
\hline$<3$ times per day & 44 & 32 & 92 & \\
\hline 3-4 times per day & 49 & 59 & 8 & \\
\hline$\geq 5$ times per day & 8 & 9 & 0 & \\
\hline Whole grain bread ${ }^{b}$ & & & & 0.663 \\
\hline$<1 /$ day & 32 & 32 & 31 & \\
\hline 1-2/day & 53 & 55 & 46 & \\
\hline$\geq 3 /$ day & 15 & 13 & 23 & \\
\hline Fish and shellfish & & & & 0.168 \\
\hline$<1$ times/week & 11 & 8 & 23 & \\
\hline 1-2 times/week & 17 & 15 & 23 & \\
\hline$\geq 2$ times/week & 73 & 77 & 54 & \\
\hline Discretionary foods ${ }^{c}$ & & & & 0.634 \\
\hline$>7$ times/week & 14 & 13 & 15 & \\
\hline 3-6 times/week & 26 & 28 & 15 & \\
\hline$<3$ times/week & 61 & 59 & 69 & \\
\hline Spread margarine ${ }^{d}$ & & & & 0.705 \\
\hline$\geq 60 \%$ & 73 & 72 & 77 & \\
\hline$\leq 40 \%$ & 27 & 28 & 23 & \\
\hline Cheese $24-40 \%$ fat & & & & 0.952 \\
\hline$\geq 4$ times/week & 61 & 60 & 62 & \\
\hline 1-3 times/week & 21 & 21 & 23 & \\
\hline$\leq 1$ times/week & 18 & 19 & 15 & \\
\hline Sausage $\mathrm{e}^{\mathrm{e}}$ & & & & 0.890 \\
\hline$>1$ times/week & 17 & 17 & 15 & \\
\hline$\leq 1$ times/week & 83 & 83 & 85 & \\
\hline
\end{tabular}

\footnotetext{
${ }^{a}$ Not including fruit juice, ${ }^{\mathrm{b}}$ Hard bread and whole grain bread, ${ }^{\mathrm{c}}$ Sweets, cakes, soft drinks, lemonade, fried potatoes,
}

${ }^{\mathrm{d}}$ Includes margarine and butter, ${ }^{\text {e }}$ Sausage and sausage dishes. 
Neither the dietary index score nor the dietary quality was related to DAS28 in unadjusted or adjusted regression analyses (Table 3). In the multivariable linear regression model (Table 3), higher dietary quality was significantly associated with lower hs-CRP. Higher dietary quality was also significantly associated with lower ESR (Table 3). When dividing dietary quality into three groups, poor quality diet was associated with higher ESR $(B=16.794, p=0.005)$ and $C R P(B=5.018, p=0.031)$ compared to a high-quality diet, in adjusted analyses. The associations between dietary quality and inflammation seemed to be driven by the indicators of fiber intake and fat quality, and less by intake of discretionary foods (Table 3).

Table 3. Associations between dietary quality and Disease Activity Score 28 (DAS28), high sensitivity C-reactive protein (hs-CRP) and erythrocyte sedimentation rate (ESR) among 66 Swedish patients with rheumatoid arthritis.

\begin{tabular}{cccccccccc}
\hline & \multicolumn{3}{c}{ DAS28 } & \multicolumn{3}{c}{ hs-CRP } & \multicolumn{3}{c}{ ESR } \\
\hline & Beta & Std. Err & $p$ & Beta & Std. Err & $p$ & Beta & Std. Err & $p$ \\
\hline $\begin{array}{c}\text { Unadjusted model } \\
\text { Dietary index score (0-12) }\end{array}$ & -0.028 & 0.073 & 0.707 & -0.560 & 0.321 & 0.086 & -1.700 & 0.743 & 0.025 \\
\hline $\begin{array}{c}\text { Adjusted model a } \\
\text { Dietary index score (0-12) }\end{array}$ & -0.020 & 0.072 & 0.787 & -0.607 & 0.295 & 0.044 & -2.420 & 0.743 & 0.002 \\
\hline Dietary quality indicators $^{\text {a }}$ & & & & & & & & & \\
Fiber intake score (0-4) $^{\text {b }}$ & -0.198 & 0.146 & 0.182 & -1.514 & 0.622 & $0.018-2.301$ & 1.107 & 0.042 \\
Fat quality score (0-6) $^{\mathrm{c}}$ & 0.093 & 0.100 & 0.359 & -0.847 & 0.429 & 0.053 & -3.545 & 1.624 & 0.033 \\
Sugar intake score (0-2) $^{\mathrm{d}}$ & -0.109 & 0.172 & 0.526 & 0.545 & 0.752 & $0.472-3.286$ & 1.909 & 0.090 \\
\hline
\end{tabular}

a Adjusted for age, body mass index, education level, smoking and gender. ${ }^{\mathrm{b}}$ Sum of score from fruit, vegetables and whole grain bread. c Sum of score of spread margarine, cheese, sausage, fish and shellfish. ${ }^{\mathrm{d}}$ Sweets, cakes, soft drinks, lemonade, fried potatoes.

There were no significant associations between dietary quality and VAS general health $(B=1.797$, $p=0.236)$, tender $(B=0.354, p=0.190)$ or swollen joint counts $(B=0.158, p=0.186)$ in adjusted analyses.

\section{Discussion}

In this study, we showed that, in patients with RA, higher dietary quality, as assessed by a dietary index based on the Swedish dietary guidelines, was associated with lower hs-CRP and ESR. However, there were no significant associations between dietary quality and disease activity, measured as DAS28.

Disease activity in RA is often measured as DAS28, which is a composite score that consists of both objective and subjective measures. The patients included in this study had a mean DAS28 of 3.4, which is considered moderate disease activity [32]. The results from our study indicated that the measures of inflammation were more noticeably associated with dietary quality than were the measures of general health and joint status. This could possibly be explained by greater variation in measures of inflammation than joint status, and that global health is a subjective measure affected by a variety of other aspects relating to wellbeing. A previous study has related dietary quality to morning stiffness, which normally correlates with DAS28, but not to hs-CRP in adjusted analyses [19]. This previous study was conducted among 84 American women and men with RA, and used the more complex Healthy Eating Index to assess dietary quality. Still, the American study did not adjust for confounders, apart from BMI, which may explain the disparate results.

The dietary index used in this study was constructed to capture the quality of dietary fat by assessing intake of fish and shellfish, spread margarine, cheese and sausage and quality of dietary carbohydrate by assessing intake of fruit and vegetables, whole grain bread and discretionary foods (including sweets, biscuits, soft drinks, lemonade and fried potatoes). The index was developed by the Swedish National Food Agency [30], and provided an estimate of dietary quality in relation to the evidence based dietary guidelines in the Nordic Nutrition Recommendations [12]. The index was 
therefore likely to have provided a relevant estimate of dietary quality. This was, to our knowledge, the first time it had been studied in relation to RA.

The dietary quality was fair for most participants but less than $10 \%$ were classified as having a high-quality diet. Hence, our sample of patients with RA had similar dietary quality compared to the general population in Sweden, where approximately $10 \%$ had a high-quality diet and an average score of approximately six points in 2008 [30]. However, the intake of fish seemed more frequent among our patients with RA, as $73 \%$ reported eating fish or shellfish at least two times/week, compared to $38 \%$ in the general population [30]. Additionally, $69 \%$ of the general population reported eating fruit and vegetables less frequently than three times/day, compared to only $44 \%$ of patients with RA. The patients with RA also reported a lower intake of discretionary foods compared to the general population. This was in line with previous data, indicating that patients with RA report that these foods worsen their symptoms [28] and they therefore might avoid them. Additionally, the patients with RA had all volunteered to participate in a dietary intervention trial, and might therefore have been more interested in diet than the general population. The dietary data from the general population were also collected in 2008, and dietary changes over time could be another explanation for any disparities in the comparisons with patients with RA. Education level and smoking were not associated with dietary quality in our analyses, perhaps due to lack of statistical power as few patients smoked and few had the highest completed education at primary level.

\section{Strengths and Limitations}

This was a cross sectional analysis and could therefore not evaluate causal relations between diet and inflammation or disease activity in RA. The small number of participants was a limitation, as was our inability to adjust for total energy intake in the present analyses. It is possible that adjusting the intake data for total energy intake may have weakened the associations found. Still, by adjusting for BMI, age and gender, the majority of variation in energy intake was likely captured. Further, only patients with an omnivore diet and who did not have food allergies or intolerances were included in the study. Inclusion of all patients with RA, despite dietary habits and avoidances, might have added an extra dimension to this work. The strengths of this study were that the patients were derived from a population-based register of high quality. In addition, the patients included in this study seemed representative of patients with RA in Sweden, though they had a slightly higher education level [1]. The diet quality index used in this study was developed by the Swedish National Food Agency, thus covering patient-relevant aspects of a healthy diet and allowing comparison with national results.

\section{Conclusions}

Higher dietary quality in patients with RA who follow an omnivorous diet was associated with lower hs-CRP and ESR. However, there was no association between dietary quality and disease activity, measured as DAS28. Well-designed dietary intervention trials are needed to confirm that a high-quality diet can reduce inflammation in patients with RA.

Author Contributions: Conceptualization, A.W., H.L., I.G. and L.B.; methodology, A.W., H.L., I.G. and L.B.; formal analysis, L.B.; investigation, A.W., H.L., I.G. and L.B.; resources, A.W., H.L., I.G. and L.B.; data curation, L.B.; Writing, original draft preparation, L.B.; Writing, review and editing, L.B., A.W., H.L., I.G.; visualization, A.W., H.L., I.G. and L.B.; supervision, A.W. and H.L.; project administration, H.L., L.B. and A.W.; funding acquisition, L.B. and A.W.

Funding: This study was funded by the Swedish government under the ALF agreement, the Swedish Research Council for Health, Working life and Welfare (FORTE), the Lennander Foundation, Sahlgrenska University Hospital Foundations, the Inger Bendix Foundation and the Gothenburg Region Foundation for Rheumatology Research.

Acknowledgments: We thank all patients with RA for their participation in the study and rheumatology nurses Marie-Louise Andersson and Anneli Lund for the clinical assessments. 
Conflicts of Interest: The authors declare no conflict of interest. The funders had no role in the design of the study; in the collection, analyses, or interpretation of data; in the writing of the manuscript, nor in the decision to publish the results.

\section{References}

1. Eriksson, J.K.; Neovius, M.; Ernestam, S.; Lindblad, S.; Simard, J.F.; Askling, J. Incidence of rheumatoid arthritis in Sweden: A nationwide population-based assessment of incidence, its determinants, and treatment penetration. Arthritis Care Res. 2013, 65, 870-878. [CrossRef] [PubMed]

2. Svensk Reumatologis Kvalitetsregister, Årsrapport 2016. Available online: http://srq.nu/srqny/wpcontent/uploads/2017/11/A\%CC\%8Arsrapport_2016.pdf (accessed on 15 October 2018).

3. Calder, P.C.; Ahluwalia, N.; Albers, R.; Bosco, N.; Bourdet-Sicard, R.; Haller, D.; Holgate, S.T.; Jönsson, L.S.; Latulippe, M.E.; Marcos, A.; et al. A consideration of biomarkers to be used for evaluation of inflammation in human nutritional studies. Br. J. Nutr. 2013, 109, S1-S34. [CrossRef] [PubMed]

4. Adam, O.; Beringer, C.; Kless, T.; Lemmen, C.; Adam, A.; Wiseman, M.; Adam, P.; Klimmek, P.; Forth, W. Anti-inflammatory effects of a low arachidonic acid diet and fish oil in patients with rheumatoid arthritis. Rheumatol. Int. 2003, 23, 27-36. [PubMed]

5. Aryaeian, N.; Djalali, M.; Shahram, F.; Djazayery, A.; Eshragian, M.R. Effect of conjugated linoleic Acid, vitamin E, alone or combined on immunity and inflammatory parameters in adults with active rheumatoid arthritis: A randomized controlled trial. Int. J. Prev. Med. 2014, 5, 1567-1577. [PubMed]

6. Jaswal, S.; Mehta, H.C.; Sood, A.K.; Kaur, J. Antioxidant status in rheumatoid arthritis and role of antioxidant therapy. Clin. Chim. Acta 2003, 338, 123-129. [CrossRef] [PubMed]

7. Vaghef-Mehrabany, E.; Alipour, B.; Homayouni-Rad, A.; Sharif, S.K.; Asghari-Jafarabadi, M.; Zavvari, S. Probiotic supplementation improves inflammatory status in patients with rheumatoid arthritis. Nutrition 2014, 30, 430-435. [CrossRef] [PubMed]

8. Macfarlane, S.; Cleary, S.; Bahrami, B.; Reynolds, N.; Macfarlane, G.T. Synbiotic consumption changes the metabolism and composition of the gut microbiota in older people and modifies inflammatory processes: A randomised, double-blind, placebo-controlled crossover study. Aliment. Pharmacol. Ther. 2013, 38, 804-816. [CrossRef] [PubMed]

9. Siemons, L.; Ten Klooster, P.M.; Vonkeman, H.E.; van Riel, P.L.; Glas, C.A.; van de Laar, M.A. How age and sex affect the erythrocyte sedimentation rate and C-reactive protein in early rheumatoid arthritis. BMC Musculoskelet. Disord. 2014, 15, 368. [CrossRef] [PubMed]

10. Lu, B.; Hiraki, L.T.; Sparks, J.A.; Malspeis, S.; Chen, C.Y.; Awosogba, J.A.; Arkema, E.V.; Costenbader, K.H.; Karlson, E.W. Being overweight or obese and risk of developing rheumatoid arthritis among women: A prospective cohort study. Ann. Rheum. Dis. 2014, 73, 1914-1922. [CrossRef] [PubMed]

11. Di Giuseppe, D.; Discacciati, A.; Orsini, N.; Wolk, A. Cigarette smoking and risk of rheumatoid arthritis: A dose-response meta-analysis. Arthritis Res. Ther. 2014, 16, R61. [CrossRef] [PubMed]

12. Nordic Nutrition Recommendations 2012: Integrating Nutrition and Physical Activity; Nordic Council of Ministers: Copenhagen, Denmark, 2014.

13. Hu, Y.; Costenbader, K.H.; Gao, X.; Al-Daabil, M.; Sparks, J.A.; Solomon, D.H.; Hu, F.B.; Karlson, E.W.; Lu, B. Sugar-sweetened soda consumption and risk of developing rheumatoid arthritis in women. Am. J. Clin. Nutr. 2014, 100, 959-967. [CrossRef] [PubMed]

14. Di Giuseppe, D.; Wallin, A.; Bottai, M.; Askling, J.; Wolk, A. Long-term intake of dietary long-chain n-3 polyunsaturated fatty acids and risk of rheumatoid arthritis: A prospective cohort study of women. Ann. Rheum. Dis. 2014, 73, 1949-1953. [CrossRef] [PubMed]

15. He, J.; Wang, Y.; Feng, M.; Zhang, X.; Jin, Y.B.; Li, X.; Su, L.C.; Liu, S.; Wang, A.X.; Chen, X.M.; et al. Dietary intake and risk of rheumatoid arthritis-a cross section multicenter study. Clin. Rheumatol. 2016, 35, 2901-2908. [CrossRef] [PubMed]

16. Damjanovic, V.; Vasilj, I.; Vlak, T.; Zelenika, D. Prevalence and risk factors of the rheumatoid arthritis in Herzegovina region in 2003-2005. Coll. Antropol. 2009, 33, 73-77. [PubMed]

17. Sundstrom, B.; Johansson, I.; Rantapaa-Dahlqvist, S. Diet and alcohol as risk factors for rheumatoid arthritis: A nested case-control study. Rheumatol. Int. 2015, 35, 533-539. [CrossRef] [PubMed] 
18. Hu, Y.; Costenbader, K.H.; Gao, X.; Hu, F.B.; Karlson, E.W.; Lu, B. Mediterranean diet and incidence of rheumatoid arthritis in women. Arthritis Care Res. 2015, 67, 597-606. [CrossRef] [PubMed]

19. Berube, L.T.; Kiely, M.; Yazici, Y.; Woolf, K. Diet quality of individuals with rheumatoid arthritis using the Healthy Eating Index (HEI)-2010. Nutr. Health 2017, 23, 17-24. [CrossRef] [PubMed]

20. Grimstvedt, M.E.; Woolf, K.; Milliron, B.J.; Manore, M.M. Lower Healthy Eating Index-2005 dietary quality scores in older women with rheumatoid arthritis v. healthy controls. Public Health Nutr. 2010, 13, 1170-1177. [CrossRef] [PubMed]

21. Hayashi, H.; Satoi, K.; Sato-Mito, N.; Kaburagi, T.; Yoshino, H.; Higaki, M.; Nishimoto, K.; Sato, K. Nutritional status in relation to adipokines and oxidative stress is associated with disease activity in patients with rheumatoid arthritis. Nutrition 2012, 28, 1109-1114. [CrossRef] [PubMed]

22. Miles, E.A.; Calder, P.C. Influence of marine n-3 polyunsaturated fatty acids on immune function and a systematic review of their effects on clinical outcomes in rheumatoid arthritis. Br. J. Nutr. 2012, 107, S171-S184. [CrossRef] [PubMed]

23. Sköldstam, L.; Hagfors, L.; Johansson, G. An experimental study of a Mediterranean diet intervention for patients with rheumatoid arthritis. Ann. Rheum. Dis. 2003, 62, 208-214. [CrossRef] [PubMed]

24. McKellar, G.; Morrison, E.; McEntegart, A.; Hampson, R.; Tierney, A.; Mackle, G.; Scoular, J.; Scott, J.A.; Capell, H.A. A pilot study of a Mediterranean-type diet intervention in female patients with rheumatoid arthritis living in areas of social deprivation in Glasgow. Ann. Rheum. Dis. 2007, 66, 1239-1243. [CrossRef] [PubMed]

25. Hafstrom, I.; Ringertz, B.; Spangberg, A.; von Zweigbergk, L.; Brannemark, S.; Nylander, I.; Rönnelid, J.; Laasonen, L.; Klareskog, L. A vegan diet free of gluten improves the signs and symptoms of rheumatoid arthritis: The effects on arthritis correlate with a reduction in antibodies to food antigens. Rheumatology 2001, 40, 1175-1179. [CrossRef] [PubMed]

26. Kjeldsen-Kragh, J. Rheumatoid arthritis treated with vegetarian diets. Am. J. Clin. Nutr. 1999, 70, 594S-600S. [CrossRef] [PubMed]

27. Kjeldsen-Kragh, J.; Borchgrevink, C.F.; Laerum, E.; Haugen, M.; Eek, M.; Forre, O.; Mowinkel, P.; Hovi, K. Controlled trial of fasting and one-year vegetarian diet in rheumatoid arthritis. Lancet 1991, 338, 899-902. [CrossRef]

28. Tedeschi, S.K.; Frits, M.; Cui, J.; Zhang, Z.Z.; Mahmoud, T.; Iannaccone, C.; Lin, T.C.; Yoshida, K.; Weinblatt, M.E.; Shadick, N.A.; et al. Diet and Rheumatoid Arthritis Symptoms: Survey Results From a Rheumatoid Arthritis Registry. Arthritis Care Res. 2017, 69, 1920-1925. [CrossRef] [PubMed]

29. Winkvist, A.; Barebring, L.; Gjertsson, I.; Ellegard, L.; Lindqvist, H.M. A randomized controlled cross-over trial investigating the effect of anti-inflammatory diet on disease activity and quality of life in rheumatoid arthritis: The Anti-inflammatory Diet In Rheumatoid Arthritis (ADIRA) study protocol. Nutr. J. 2018, 17, 44. [CrossRef] [PubMed]

30. Wolf, B. Indikatorer för Bra Matvanor-Resultat från Intervjuundersökningar 2008; National Food Agency: Uppsala, Sweden, 2009.

31. Monfort-Pires, M.; Folchetti, L.D.; Previdelli, A.N.; Siqueira-Catania, A.; de Barros, C.R.; Ferreira, S.R. Healthy Eating Index is associated with certain markers of inflammation and insulin resistance but not with lipid profile in individuals at cardiometabolic risk. Appl. Physiol. Nutr. Metab. 2014, 39, 497-502. [CrossRef] [PubMed]

32. Singh, J.A.; Saag, K.G.; Bridges, S.L., Jr.; Akl, E.A.; Bannuru, R.R.; Sullivan, M.C.; Elizaveta Vaysbrot, E.; McNaughton, C.; Osani, M.; Shmerling, R.H.; et al. 2015 American College of Rheumatology Guideline for the Treatment of Rheumatoid Arthritis. Arthritis Rheumatol. 2016, 68, 1-26. [CrossRef] [PubMed]

(C) 2018 by the authors. Licensee MDPI, Basel, Switzerland. This article is an open access article distributed under the terms and conditions of the Creative Commons Attribution (CC BY) license (http:/ / creativecommons.org/licenses/by/4.0/). 